\title{
Design and fabrication of pneumatic charcoal kiln drying characteristics and residence temperature for cat fish smoking
}

\author{
${ }^{1}$ Idi-ogede A.M, ${ }^{2^{*}}$ Ogori A.F and ${ }^{3}$ Omoniyi S.A \\ ${ }^{1}$ Department of fisheries and Aquaculture Federal university Gashua PMB 1005 Yobe state Nigeria \\ ${ }^{2,3}$ Department of Home Science and Management, Federal university Gashua PMB1005 Yobe state, Nigeria \\ Corresponding Author Email: ogorifaraday@gmail.com
}

\begin{abstract}
The fabrication of pneumatics charcoal kiln for fish smoking was done with the objectiveof replacing the existing open kiln smoking of fish. The pneumatic kiln of rectangular metal plate made from wrought iron of $2 \mathrm{~mm}$ thickness has three chambers: The fan chamber, powered by a solar energy, charcoal chamber and the smoke chambers respectively. The chambers were insulated with $20 \mathrm{~mm}$ thick thermosetting polymer which is welded inbetween two wroughtirons. At the end of the smoke chambers is connected a pneumatic pump pipe that further assists in heat convective flow mechanism during operation. The kiln is operated autmatedly by switching in the fanset button. The machine performance was evaluated using cat fish, smoked to an average moisture content of $47.1 \%$ within an average time span of $1 \mathrm{~h}$, and the average final weight of the dried fish was $1.03 \mathrm{Kg}$. It was projected that increasing time for drying from 2-3 hours and maintaining residence temperature of $60-83^{\circ} \mathrm{C}$, pneumatic charcoal kiln could become best potential fish kiln that can keep fish longer without further spoilage.
\end{abstract}

Keyword: Cat Fish, Pneumatics kiln, Moisture content, Temperature, Smoke charcoal, Chambers

\section{INTRODUCTION}

Drying is one of the essential unit operations performed to increase the shelf life of agricultural or horticultural produce and it is one of the most practical methods of preserving food and the quality of agricultural produce .(Ashok et al. , 2015).

Traditionally, fish food produce are dried by spreading in open sun in thin layer and smoking using wood. Though this method is economical and simple, it has the draw backs like; no control over the rate of drying, nonuniform drying, chances of deterioration due to exposure of products against rain, dust, storm, birds, rodents, insects and pests which results in poor quality of dried products .Whereas, kiln pneumatic drying system leads to fast rate of smoke- drying and exposure of products against rain, dust, storm, birds, rodents, insects and pests may obviously be avoided. Against this, open sun drying and smoke processing drying requires longer drying time and product quality are however difficult to control because of inadequate drying, high moisture, fungal growth and encroachment of insects, birds and rodents ,as well as economy of space(Ashok et al ,2015). Drying is usually conducted by vaporizing water in the product (Fellow, 1988).

Thus; the latent heat of vaporization must be supplied. Airflow is also required to remove the vapor away from the product. The lower the humidity of hot air supplied to the drying chamber, the better the drying rate, as the less humid air can carry more moisture from the product surface than the more humid air. Generally, increasing the temperature and velocity shortens the drying time hence pneumatic processing. For heat-sensitive products, such as fish food and pharmaceutical products, 
high temperature decreases product quality. In this case, drying at low temperature and humidity is required to maintain the fresh color of the product using the desiccant system.(Ashok et al ,2015)

Dried fish production in one country does not vary much from another. (Rene,1987). In most cases, fish drying (cat fishes) process in the rural areas is done in the same manner as the old practice fifty years ago (Rene,1987). A break through to quality and economic catfish smoke- drying production methods is very limited. In many state, all over the country, catfish is sold to the market in poor quality condition.

Usually percentage of spoilage is high because required moisture content and the water activity in the product after drying completion is above the desired requirement with attendant mold growth and bacteria. (Rene,1987). Un-dried fish are easy target of insects and bacteria which result to foul smell, decay and deterioration. Double handling of fish product is rampant (Ekechukwu , 1987).

Maximum drying rates are desired though product quality must be considered. During drying, some tissue have a tendency to form dry surface layers which are impervious to subsequent moisture transfer if the drying rate is very rapid. To avoid this requires effective control of the drying process. The heat transfer and evaporation rates must be closely controlled to guarantee optimum drying rates. The control of the drying process in naturalcirculation dryers presents a major problem ;( Ekechukwu and Norton, 1999), as such dryers are made to minimize capital and running costs. The best approach is to incorporate into the design of the dryers such structural features that would guarantee that extreme conditions not to prevail in the dryer under the envisaged climatic conditions and crop properties ;( Ekechukwu and Norton, 1999)

Drying characteristic of product is one of the many important factors that provide criteria in the selection and aspects in the choice of design and method of operation of drying plants.. Most of the fish harvested in the tropics is used for direct consumption but a great deal is processed into fish meal for use in compounding feeds (Eyo, 2001). But a great deal is processed into fish meal for use in compounding feeds (Eyo, 2001). Also according to Eyo (2001), a significant quantity is lost as a result of the absence of adequate technology to prevent spoilage.

\section{RESEARCH METHODOLOGY}

\section{Design calculation}

Volume of the kiln: kiln capacity is related to the volume Volume of pneumatic kiln smoking chamber $\mathrm{Vp}=\mathrm{L} \times \mathrm{b} \times \mathrm{h}$
Where

$\mathrm{L}=$ length of the smoking chamber $=0.609 \mathrm{~m}$

$\mathrm{B}=$ width of smoking chamber $=0.914 \mathrm{~m}$

$\mathrm{H}=$ Height of smoking chamber $=0.609 \mathrm{~m}$

$V_{P}=0.609 \times 0.914 \times 0.609=0.338 \mathrm{~m}$

\section{Volume of charcoal chamber}

$$
=338 \mathrm{~cm}^{3}
$$

$\mathrm{Vc}=\mathrm{L} \times \mathrm{b} \times \mathrm{h}$

Where $L=$ length of charcoal chamber $=0.457 \mathrm{~m}$

$\mathrm{b}=$ width of charcoal chamber $=0.305 \mathrm{~m}$

$\mathrm{h}=$ height of charcoal chamber $=0.457 \mathrm{~m}$

$\mathrm{V} c=0.457 \times 0.305 \times 0.457$

$=0.0636 \mathrm{~m}$ or $63.6 \mathrm{~cm}^{3}$

\section{Diameter of fan blower at a fixed position}

Moment $=\mathrm{f} \times$ length or (height)---------(3)

Where $\mathrm{f}=50$ watt

$$
\begin{aligned}
& \mathrm{L}=0.305 \mathrm{~m} \\
& =50 \times 0.305=15.25 \mathrm{Nm}
\end{aligned}
$$

Velocity of air into the productChamber from fan blower

$$
V_{a}=d / t---------(4)
$$

Where $d=$ distance from fan position to end of smoking chamber $=0.1525 \mathrm{~m} \times 0.305 \mathrm{~m} \times 0.914 \mathrm{~m}$

$=0.0426 \mathrm{~m}^{3}$

$\mathrm{T}=$ time insecond

But $F=1 / T$

$$
\mathrm{FT}=1
$$

But $T=1 / F$ where $F=50 \mathrm{~Hz}$. Given

Therefore $V_{a}=0.0428 \mathrm{~m} \div 0.02=0.042 \div 0.02=2.13 \mathrm{~m} / \mathrm{s}$. Heat transfer by conduction is obtained as :

$$
q=\frac{K A T,-T 2--}{L}
$$

Where

Thermal conductivity $\mathrm{K}=59 \mathrm{wm} / \mathrm{k}$

$A=$ area of the fish tray $=\mathrm{Ixb}=0.609 \times 0.914$

$=0.556 \mathrm{~m}^{2}$

$\mathrm{L}=$ distance between the smoking chamber and the charcoal chamber $=2 \mathrm{~m}$.

$\mathrm{T}_{1}=$ temperature of the inside smoking chamber $=38.9^{0} \mathrm{C}($ assumed $)$

(assumed)

$\mathrm{T}_{2}=$ temperature of the outside $=36.8{ }^{0} \mathrm{C}$

$\mathrm{q}=\frac{59 \times 0.609 \times 0.914(38.9-36.8)}{2}$

$q=34.48 \mathrm{~J} / \mathrm{m}^{2}$.

\section{MATERIAL AND CONSTRUCTION}

Chaka plate (wrought iron) metal sheet of $2 \mathrm{~mm}$ was used for construction of all the chambers. The fan chamber, charcoal chamber and the smoking chamber. The 


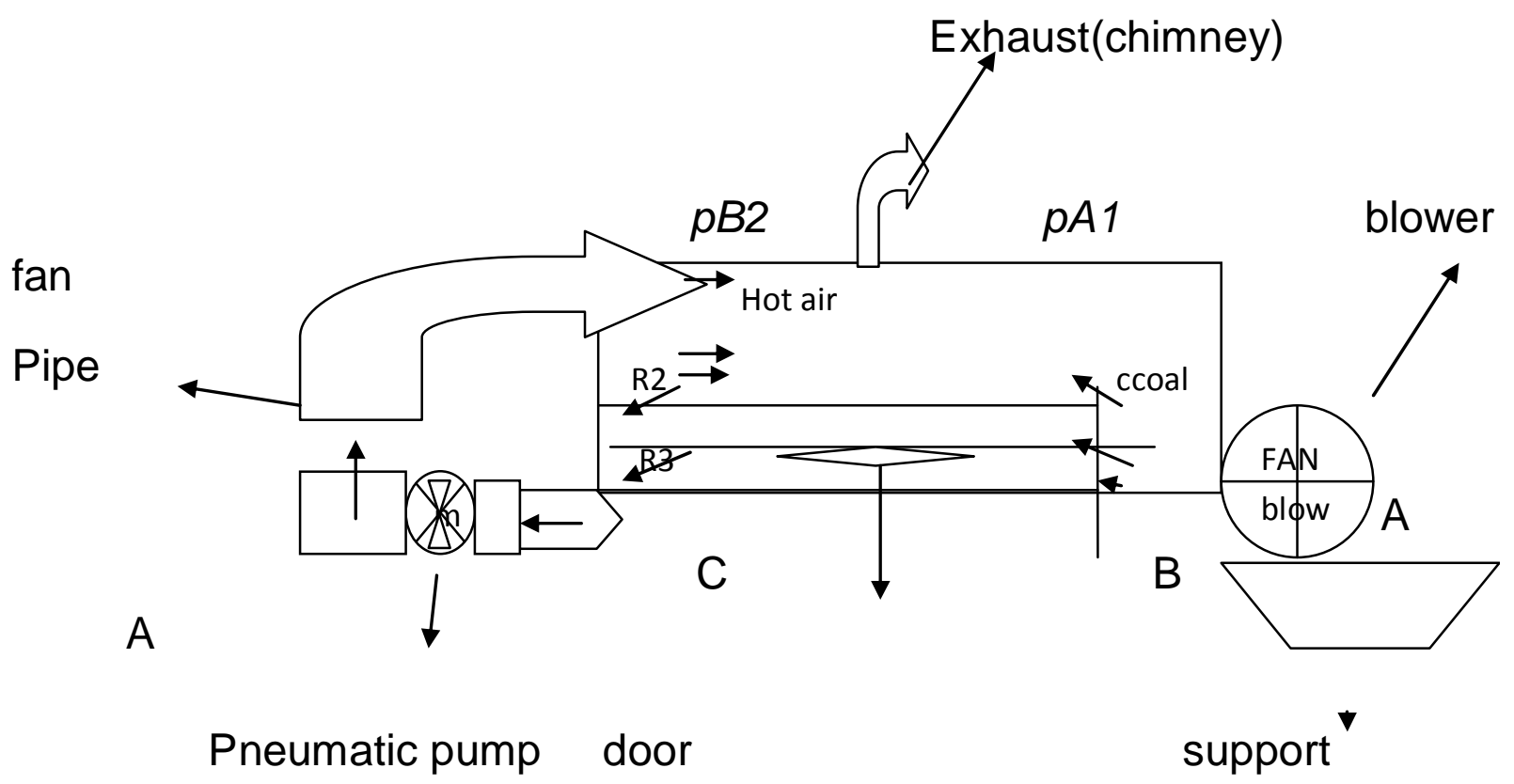

Figure 1.Pneumatic Charcoal Kiln

charcoal and the smoking chambers were insulated with a thermosetting polymer of $100 \mathrm{~mm}$ thickness. These were welded to a fit tight position. The fan chamber has $0.457 \mathrm{~m} \times 0.305 \mathrm{~m} \times 0.457 \mathrm{~m}$ as the length, width and height respectively. The charcoal chamber has $0.457 \mathrm{~m} \times 0.305 \mathrm{~m} \times 0.457$ as the length, width and height respectively. The smoking chamber has $0.609 \mathrm{~m} \times 0.914 \mathrm{~m} \times 0.609 \mathrm{~m}$ as the length, width and height dimensions. See figure 1 below.

The pneumatic pump fitted at the other width base would be adjusted to allow recycling of warm air back into the kiln chamber. At the junction of inlet pneumatic pipe, chimney outlet and hot air inlet interphase, less dense air mass would escape, such as fish methane and propyl compounds. See figure (1). Pneumatic charcoal kiln was design and fabricated with the aim of fulfilling the following objectives: safety in quality and economy of labour, efficiency in performance.

The motor/fan: these are fixed on the width of the fan chamber connected to a solar panel with a regulator attached to control the blade speed.

The fish trays:It is a container meshed in a rectangular form of $0.0609 \mathrm{~m} \times 0.914 \mathrm{~m}$ length and width dimension. Each fixed at a distance of $0.122 \mathrm{~m}$ from each other, in the smoking chamber. $R_{1}$ and $R_{2}$.

The pneumatic system: is a pipe connected from the center of the chamber up length to the width center with a pneumatic pump of $25 \mathrm{psi}$. This is welded to circulate heated air within the chamber through the connected pipe Pneumatic charcoal kiln assembly: The fan chamber, charcoal chamber, smoking chamber and the pneumatic pump were welded together making a complete pneumatic kiln figure 1 depicts.

\section{RESULTS}

\section{Operation of the pneumatic charcoal kiln}

The cat fish to be smoked were washed; weighted and placed on the wire gauge meshed trays and charged into the smoking chamber. The charcoal is lit, the burning charcoal supplies heat which dries the fish. The fan is regulated and blows air through the charcoal chamber into the smoking chamber through a meshed opening or aperture of $8 \times 8 \mathrm{~m}$. The ash drops at the base from the charcoal chamber after each process by sliding out a metal cover.

\section{Performance evaluation}

Cat fish were obtained from Gashua fish market. The samples were thoroughly washed, drained, weighed and charged into each tray.

The charcoal on the charcoal chamber was first ignited using kerosene and allowed to burn for 6-10 minute, this allow odour of kerosene to go up and then charcoal added.

The tray one has about $1.5 \mathrm{~kg}$. Tray 2 also has $1.5 \mathrm{~kg}$ of fish. The fan was set in motion of speed one and timed. During the smoking process, the help of the pneumatic system and the closure of the smoking chamber allow 
088 Afr. J. Food Sci. Technol.

Table 1. Drying Performance

\begin{tabular}{lcccc}
\multicolumn{2}{l}{ Tray No. Initial weight(w1) $\mathbf{~ k g}$} & Time taken $(\mathbf{m i n})$ & Final weight (w2) $\mathbf{~ k g}$ & \% MC \\
\hline 1 & 1.5 & 60 & 1.1 & 36.3 \\
2 & 1.5 & 60 & 0.95 & 57.9 \\
Min & 1.5 & 60 & 1.025 & 47.1 \\
\hline
\end{tabular}

Table 2. Resident temperature

\begin{tabular}{|c|c|c|}
\hline Tray No. & time $(\min )$ & $\left(\mathrm{PA}^{1}\right) \mathrm{T}_{0} \mathrm{~T}_{2}\left({ }^{0} \mathrm{C}\right)\left(\mathrm{PB}^{2}\right) \mathrm{T}_{0} \mathrm{I}_{2}\left({ }^{0} \mathrm{C}\right)$ \\
\hline 1 & 60 & $\begin{array}{ll}(85.8) 302,116 & (63.8) 30.2,94\end{array}$ \\
\hline 2 & 60 & (81.5)30.1,111.6 (56.9) 30.1, 87.1 \\
\hline Mean & 60 & 83.6 \\
\hline
\end{tabular}

for convective heat flow which disallow turning the fishes side to side or upside down. The smoking process was allowed after $60 \mathrm{~min}$ on temperature of the chamber after every $30 \mathrm{~min}$ and the temperature of the chamber taken to ascertain resident temperature of the smoking chamber at the two ends of the smoking chamber, $\mathrm{P}^{\mathrm{A1}} / \mathrm{P}^{\mathrm{B} 2}$ respectively, figure 1 above.

The moisture content of $47.1 \%$ calculated from equation (6) is above the $10-15 \%$

Safety moisture content of dried fish according to (Ikenweiweet al 2015). After the 60 min smoking process the fish is allowed to cool in a plastic container.

Mc (dry basis )\% = Initial weight (w1)- Final weight $\mathrm{X} 100$

Final weight

Where

Mcdb = moisture content by dry basis in percentage Initial weight $=$ weight of drained fish in $\mathrm{kg}$

Final weight $=$ weight of smoked fish after $60 \mathrm{~min}$ in $\mathrm{kg}$

\section{DISCUSSION}

The design and fabricated pneumatic charcoal kiln smoking machine was rigid and operate perfectly with no manual effort to operation. The pneumatic kiln was tested with fresh cat fish of $1.5 \mathrm{~kg}$ on each tray. See table 1.

Table one above shows that the short time given (1hr) the moisture contents was averagely low, though not to a safe level. By projection 4-5 hours smoking will reduce the moisture contents to a safety level of between
(8-9\%) taking into consideration the weight/size of the fish, initial moisture content, fat content, and heat dynamics in the smoking chamber as well as intensity of heat supplied (Adamu et al 2013), see table 2 .

This machine is found to be potentially useful above the local method of smoking fish that normally spans through 24 hours in addition to intensive labour and heat skin laison effects. The residence temperature of 83.6 and $60.4{ }^{\circ} \mathrm{C}$ in the chamber maya increases drying rate by recycling drying process. Table 2

\section{CONCLUSION}

Pneumatic charcoal smoking kiln that is easy to operate, requiring no energy cost, potable and easy to maintain was design and fabricated. The pneumatic kiln was tested using cat fish. The kiln efficiency is predictable within an hour of smoking process. This machine could beused for drying and re-drying of fish and other soft tissue of animal and plant food sources.

\section{ACKNOWLEDGEMENT}

The authors acknowledged the grant received from The Tertiary Education Trust Fund (TetFund) through the Federal University, Gashua, Nigeria that made it possible to carry out this research work.

\section{REFERENCES}

Adamu IG1, Kabri HU, Hussaini ID, Mada A D.(2013) Design and construction of fish smoking kiln . J. Engr. and Technol. Res. Vol. 5(1), pp. 15-20,

Ashok Kumar, Moses CC, Kalay Khan(2015).A survey on the design, fabrication and utilization of different types of food and vegetable dryes.IOSR j. Agric and vet. Sci. vo 8 p59-68 
Idi-ogede et al. 089

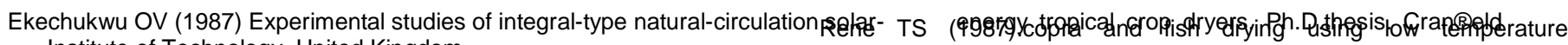
Institute of Technology, United Kingdom.

Ekechukwu OV, Norton B(1999) Review of solar-energy drying systems II: an Management (40) 615-655

geothermal energy. Geothermal training program, united nation QYiarueiesty 


\section{KEYS;}

$\mathrm{R}=$ Racks

$p A_{1}=$ positional one of kiln chambers

$\mathrm{pB}_{2}=$ positional two of kiln chambers

$\mathrm{A}=\mathrm{Fan}$ chamber

$\mathrm{B}=$ charcoal chamber

$\mathrm{C}=$ smoking chamber 